\title{
Effect of skipping irrigation on growth, yield, yield components and water use efficiency of wheat (Triticum aestivum L.) in semi arid Region of Sudan
}

\author{
Al Tahar Bstawi Ali El Hwary ${ }^{1}$, Samia Osman Yagoub ${ }^{2}$ \\ ${ }^{1}$ New Halfa Agricultural Corporation, New Halfa, Sudan. \\ ${ }^{2}$ Department of agronomy, College of Agricultural Studies, Sudan University of Science and \\ Technology.www.sustech.edu.
}

\begin{abstract}
The study was conducted for two consecutive winter seasons (2008/09-2009/10) at the Demonstrated Farm, Sudan University of Science and Technology, Shambat, Sudan to study the effect of skipping one irrigation during different developmental stages on growth, yield, yield components and water use efficiency of wheat (Triticum aestivum L.). Condor cultivar was grown under six irrigation treatments at developmental growth stage, in which one-irrigation was skipped at some of growth stages (seedling $W_{1}$, tillering $W_{2}$, booting $W_{3}$, dough $W_{4}$ and repining stage $W_{5}$ ) and irrigation without skipping with intervals of 10 days as control $W_{S}$. The experimental design was randomized complete block design with four replications. The parameters studied were: plant height, dry matter accumulation, plant $/ \mathrm{m}^{2}$, tiller/plant, number of spike $/ \mathrm{m}^{2}$, spikelet/spike, grain/spike, 1000-grain weight, grain yield, straw yield, biomass, harvest index, water use efficiency. The results showed there were highly significant differences in all tested parameters due to skipping irrigation except plant $/ \mathrm{m}^{2}$ in both seasons, and plant height and dry matter accumulation in 45 days reading (booting stage) in the second seasons. Irrigation every 10 days throughout (control) gave higher values (few different with seedling and repining stages) than the other sensitive stages. Although, the resulted showed highly significant effect on the studied parameters biomass, straw and grain yield, harvest index, water use efficiency and protein content. In general irrigation every 10 days with slightly different at skipping on seedling and repining stages gave the highest protein content, grain and straw yield and field water use efficiency. Skipping irrigation during tillering and booting stage must be avoided.
\end{abstract}

Keywords: Wheat, Skipping irrigation, Growth stage, Yield, Semi-arid, Sudan.

\section{INTRODUCTION}

Wheat (Triticum aestivum L.) is the main staple food for the $35 \%$ of the world's population. It is planted on about 100 million hectares in the developing world. Global wheat production is concentrated mainly in Australia, Canada, China, Europe, India, Pakistan, Russia, Turkey, Ukraine and United States, accounting for over $80 \%$ of world wheat production (FAO, 2007). Wheat has the largest cultivated area among the various crops plants (Ferrar et. al. 1994). Like some other crops, wheat is subjected to many biotic and a biotic stresses, which reduce yield and affect yield stability. The abiotic stresses include drought, heat, water logged, soils and soils with toxic levels of boron. All of these can pose serious problem for wheat farmer, especially in the less-favored growing environment. In addition to abiotic, there are also many biotic or living stresses such as diseases, insects and weeds, which can reduce wheat yields.
Wheat in the Sudan being a temperate crop, it is not indigenous to Sudan; yet it was traditionally grown since early time in the Northern State (latitude 18 $22 \mathrm{~N}$ ) that enjoys a relatively cooler and longer winter season than in the central Sudan, (Mohemmed, 2009). Demand for wheat in the past has not been very high because the diet of the majority of the Sudanese population was based mainly on Sorghum. At present, wheat consumption has increased and the government is attempting to attain self-sufficiency in this commodity. Wheat production under semi-arid conditions of Sudan is now success. Grain yield of over 5 tons/hectare were obtained with high technology use. However, lack of yield stability over seasons and location has remained a great challenge to both research and production management (Babiker and Faki, 1994). The crop is grown entirely irrigation with water, either from river flows, as in Gezira, New Halfa and the White Nile Agricultural 
Schemes, or lifted from the River Nile and wells using diesel pumps, as in the Northern State (Farah, 1994a). Detection of crop water stress is critical for efficient irrigation water management, especially in the semi-arid regions. The recommended number of watering and irrigation regimes at the vegetative and the reproductive stages need to be applied properly and timely for better yields. Furthermore, low soil moisture conditions reduce the number of reproductive tillers which limit their contribution to grain yield (McMaster, 1999). On the other hand, irrigation water is becoming increasingly scares; this highlights the importance of the effective and efficient use of this resource. Therefore, the objectives of this study was to investigate effects of skipping irrigation on growth, yield, yield components and water use efficiency (WUE) of wheat, and find out the appropriate system of irrigation regimes for the increase in production of wheat.

\section{MATERIALS AND METHODS}

The study was conducted for two consecutive winter seasons (2008/09-2009/10) at the Demonstrated Farm, Sudan University of Science and Technology, Shambat, Sudan to study the effect of skipping one irrigation on growth, yield, yield components and water use efficiency of wheat (Triticum aestivum L.). Condor cultivar was grown under six irrigation treatments at developmental growth stage, in which one-irrigation was skipped at some of growth stages as well as following:

$\mathrm{W}_{\mathrm{S}}=$ Irrigation every 10 day throughout the season (control).

$\mathrm{W}_{1}=$ Skipped from $(11-20$ days) at (seedling stage).

$\mathrm{W}_{2}=$ Skipped from (31 - 40 days) at (tillering stage).

$\mathrm{W}_{3}=$ Skipped from (51 - 60 days) at (booting stage).

$\mathrm{W}_{4}=$ Skipped from (71-80 days) at (dough stage).

$\mathrm{W}_{5}=$ Skipped from (above 80 days) at (repining stage).

Each treatment was repeated four times by using Randomize Complete Block Design in both seasons.

The parameters studied were: plant height $(\mathrm{cm})$, dry matter accumulation (g), plant $/ \mathrm{m}^{2}$, tiller/plant, spike $/ \mathrm{m}^{2}$, spikelet/spike, grain/spike, 1000-grain weight $(\mathrm{g})$, grain yield $(\mathrm{kg} / \mathrm{ha})$, straw yield (kg/ha), biomass (kg/ha), harvest index
(\%) and water use efficiency $(\mathrm{mm} / \mathrm{kg} / \mathrm{ha})$ was calculated using the equation of $\mathrm{Ali}$ and Talukder, (2008) for grain yield as follow:

WUE $(\mathrm{kg} / \mathrm{mm} / \mathrm{ha})$

$=\underline{\text { Grain or seed yield } \mathrm{kg} / \mathrm{ha}}$

Water applied to the field $\mathrm{mm} / \mathrm{ha}$

The data of plant parameters were analyzed year wise on individual basis and their means were computed. Statistical analyses for ANOVA were conducted by using "MSTAT-C" (Anonymous, 1986) where as the means were compared through (LSD) test Least Significant Different (Steel et al., 1997) at $\mathrm{P}=0.05$ and Excel program to illustrate and compared data on figures.

\section{RESULTS AND DISCUSION}

The adequate supply of irrigation water is the main factor affecting directly in the growth and productivity of wheat plant. Water supply is limiting factor for crop production for sustainable agriculture, it is desirable to obtain higher grain yield using the least amount of irrigation water. In general, the results showed that means growth and yield attributes of wheat under skipping irrigation at development growth stages of wheat was relatively lower in the first season than in the second season. The growth and yield attributes of the well watered treatments (skipped at not sensitive stages) exceed that of the stressed treatments in all sampling occasions. In the two seasons studied, the results were obtained taller plant at full irrigation (control $W_{S}$ ) and skipping during dough $W_{4}$ and repining $W_{5}$ stages compared to shorter plant at skipping during seedling $W_{1}$, tilleing $W_{2}$ and booting $\mathrm{W}_{3}$ (Table 1, Fig. $1_{\mathrm{a}}, 1_{\mathrm{b}}$ ). Extensive research work on stressing wheat for water at specific stages of plant growth resulted in shorter plants when the stress was at jointing (stem-elongation) and booting or at vegetative and flowering stages, Haikl and Melegy, (2005) reported that the positive effect for irrigation on plant height may be attributed to the effect of irrigation on the encouragement of cell elongation, cell division and consequently increase merestemic growth. 
Agric. Biol. J. N. Am., 2011, 2(6): 1003-1009

Table 1: Effect of skipping irrigation on plant height $(\mathrm{cm})$ at developmental growth stage of wheat during 2008/09 and 2009/010 seasons:

\begin{tabular}{|c|c|c|c|c|c|c|c|c|c|c|}
\hline \multirow{2}{*}{$\begin{array}{l}\text { Treat } \\
\text { ments }\end{array}$} & \multicolumn{5}{|c|}{$2008 / 09$} & \multicolumn{5}{|c|}{$2009 / 010$} \\
\hline & $\begin{array}{l}\text { Plant } \\
\text { height } \\
15\end{array}$ & $\begin{array}{l}\text { Plant } \\
\text { height } \\
30\end{array}$ & $\begin{array}{l}\text { Plant } \\
\text { height } \\
45\end{array}$ & $\begin{array}{l}\text { Plant } \\
\text { height } \\
60\end{array}$ & $\begin{array}{l}\text { Plant } \\
\text { height } \\
75 \text { days }\end{array}$ & $\begin{array}{l}\text { Plant } \\
\text { height } \\
15\end{array}$ & $\begin{array}{l}\text { Plant } \\
\text { height } \\
30\end{array}$ & $\begin{array}{l}\text { Plant } \\
\text { height } \\
45\end{array}$ & $\begin{array}{l}\text { Plant } \\
\text { height } \\
60\end{array}$ & $\begin{array}{l}\text { Plant } \\
\text { height } \\
75 \text { days }\end{array}$ \\
\hline $\begin{array}{l}W_{S} \text { without } \\
\text { skipping }\end{array}$ & $20.9 a$ & $35.5 a$ & $53.0 a$ & $66.3 a$ & $66.3 a$ & $20.9 b$ & $32.8 a b$ & $52.6 a$ & $71.8 a$ & $71.8 a$ \\
\hline $\begin{array}{l}W_{1} \text { skipping } \\
\text { at seedling }\end{array}$ & $16.9 b$ & $30.9 b$ & $48.8 b$ & $56.6 \mathrm{c}$ & $62.6 \mathrm{~b}$ & $16.2 \mathrm{c}$ & $28.7 \mathrm{c}$ & $50.2 a$ & $65.9 \mathrm{~b}$ & $65.9 \mathrm{~b}$ \\
\hline $\begin{array}{l}W_{2} \text { skipping } \\
\text { at tillering }\end{array}$ & $21.3 a$ & $36.3 a$ & $49.3 b$ & $57.7 \mathrm{c}$ & $57.7 \mathrm{c}$ & $21.7 \mathrm{~b}$ & $33.0 \mathrm{ab}$ & $51.0 a$ & $70.1 \mathrm{ab}$ & $70.1 \mathrm{ab}$ \\
\hline $\begin{array}{l}W_{3} \text { skipping } \\
\text { at booting }\end{array}$ & $20.7 a$ & $36.1 \mathrm{a}$ & $54.3 a$ & $62.5 \mathrm{~b}$ & $62.5 b$ & $22.0 \mathrm{~b}$ & $32.6 \mathrm{~b}$ & $53.1 \mathrm{a}$ & $66.8 \mathrm{~b}$ & $66.8 \mathrm{~b}$ \\
\hline $\begin{array}{l}\text { W }{ }_{4} \text { skipping } \\
\text { at dough }\end{array}$ & $20.7 a$ & $36.9 a$ & $55.6 a$ & $65.8 \mathrm{ab}$ & $65.6 \mathrm{ab}$ & $21.4 b$ & $36.0 a$ & $53.5 a$ & $72.9 a$ & $72.9 a$ \\
\hline $\begin{array}{l}W_{5} \text { skipping } \\
\text { at repining }\end{array}$ & $21.4 a$ & $36.4 a$ & $54.4 a$ & $65.5 \mathrm{ab}$ & $66.8 a$ & $23.3 a$ & $31.5 b c$ & $53.5 a$ & $72.9 a$ & $72.9 a$ \\
\hline LSD & 1.52 & 1.86 & 3.07 & 3.11 & 3.13 & 1.21 & 3.22 & 4.15 & 4.46 & 4.46 \\
\hline $\mathrm{SE}=$ & 0.74 & 1.0 & 0.9 & 1.0 & 1.0 & 0.40 & 1.1 & 1.5 & 1.5 & 1.5 \\
\hline CV\% & 5.0 & 3.5 & 3.9 & 3.3 & 3.3 & 3.3 & 6.6 & 5.4 & 4.9 & 4.2 \\
\hline
\end{tabular}

Means with the same letter in each column are not significant at 0.05 level of (LSD) test.

High dry matter production is an important perrequisite for high grain yield. In the present study (Table 2) dry matter accumulation, although insensitive to water deficient, was consistently reduced under water stress. Supporting evidence was reported by (Squie et al., 1989) who observed that the simple linear relationship between dry matter production and radiation interception break down when water is in short supply. The present finding showed that in both seasons dry matter accumulation was consistently greater by full irrigation $W_{S}$ and skipping at dough and repining stages gave higher dry matter accumulation than skipping at seedling, tillering and booting stages in both seasons. Similar results were found by Cooper, (1980) and Steiner et al., (1985). The reduction in dry matter accumulation may be attributed to unbalanced soil water-air relations that let to reducing the photosynthesis activity and unbalanced relations between plant hormones and biological processes in the whole plant organs, (Schneider and Howell, 1997.

The results in table (3) showed that highest values of plant $/ \mathrm{m}^{2}$ and surviving tillers were associated with the skipping irrigation at tillering, booting, dough and ripining stages in both seasons. The more number of tillers may be attributed to adequate moisture supply particularly at tillering stage, (Bajwa et al., 1993) observed significant effect on varying levels of irrigations on the number of tillers $/ \mathrm{m}^{2}$

It is of course known that the final yield of wheat is the product of the number of spike $/ \mathrm{m}^{2} \mathrm{x}$ spikelet/spike $x$ grain/spike $x$ weight of grains. However, the skipping irrigation treatments (Table 4) in this study showed different effects on the components of yield. Full irrigation (control) and skipping at seedling, dough and ripening stage gave higher number of spike $/ \mathrm{m}^{2}$, spikelet/spike, grains/spike and 1000-grain weight. Bajwa et al (1993) observed significant effect on varying levels of irrigations on the yield components. Under favorable conditions, the most favorable treatments in this study (full irrigation and skipping at seedling, dough and repining stages) gave the highest values of components, and unfavorable treatment (skipping at tillering and booting stages) recorded the lowest values of yield components in the two seasons. These results are in agreement with those obtained by Awad et al., (2000). The maximum number of grains/spike obtained may be due to suitable moisture available at those treatments. The previous studies also revealed that number and time of irrigations significantly in flounced number of grains/spike (Hussain, 1996; Akram, 2000). Bajwa et al., (1993) also observed that the different levels of irrigations significantly affected 1000-grain weight. 
Agric. Biol. J. N. Am., 2011, 2(6): 1003-1009

Table 2: Effect of skipping irrigation on dry matter accumulation (g) at developmental growth stages of wheat during 2008/09 and 2009/010 seasons:

\begin{tabular}{|c|c|c|c|c|c|c|c|c|c|c|}
\hline \multirow{3}{*}{$\begin{array}{l}\text { Treat } \\
\text { ments }\end{array}$} & \multicolumn{5}{|c|}{$2008 / 09$} & \multicolumn{5}{|c|}{$2009 / 010$} \\
\hline & $\begin{array}{l}\text { Dry } \\
\text { matter }\end{array}$ & $\begin{array}{l}\text { Dry } \\
\text { matter }\end{array}$ & $\begin{array}{l}\text { Dry } \\
\text { matter }\end{array}$ & $\begin{array}{l}\text { Dry } \\
\text { matter }\end{array}$ & $\begin{array}{l}\text { Dry } \\
\text { matter }\end{array}$ & $\begin{array}{l}\text { Dry } \\
\text { matter }\end{array}$ & $\begin{array}{l}\text { Dry } \\
\text { matter }\end{array}$ & $\begin{array}{l}\text { Dry } \\
\text { matter }\end{array}$ & $\begin{array}{l}\text { Dry } \\
\text { matter }\end{array}$ & $\begin{array}{l}\text { Dry } \\
\text { matter }\end{array}$ \\
\hline & 15 & 30 & 45 & 60 & 75days & 15 & 30 & 45 & 60 & 75days \\
\hline $\begin{array}{l}W_{S} \\
\text { without } \\
\text { skipping }\end{array}$ & $8.2 a$ & $34.5 a$ & $53.4 \mathrm{~b}$ & $82.7 a$ & $107.8 a$ & $4.5 a b$ & $27.1 \mathrm{ab}$ & $46.6 a$ & $85.2 b$ & 109.0ab \\
\hline $\begin{array}{l}W_{1} \text { skipping } \\
\text { at seedling }\end{array}$ & $3.9 \mathrm{c}$ & $25.7 b$ & $49.9 b$ & $77.5 a b$ & $91.5 b$ & $2.9 d$ & $19.9 c$ & $42.9 a$ & $75.9 b c$ & $103.2 b$ \\
\hline $\begin{array}{l}W_{2} \text { skipping } \\
\text { at tillering }\end{array}$ & $6.9 \mathrm{~b}$ & $30.5 a b$ & $45.7 b$ & $67.3 \mathrm{bc}$ & $80.5 c$ & $3.8 \mathrm{c}$ & $26.2 b$ & $43.6 a$ & $73.5 c$ & $89.8 c$ \\
\hline $\begin{array}{l}\text { W }_{3} \text { skipping } \\
\text { at booting }\end{array}$ & $7.0 \mathrm{~b}$ & $29.6 a b$ & $48.0 \mathrm{~b}$ & $60.5 c$ & $66.4 d$ & $3.9 \mathrm{bc}$ & $26.1 \mathrm{~b}$ & $46.2 a$ & $74.4 \mathrm{c}$ & $86.1 \mathrm{c}$ \\
\hline $\begin{array}{l}\text { W }{ }_{4} \text { skipping } \\
\text { at dough }\end{array}$ & $7.2 \mathrm{~b}$ & $36.2 a$ & $54.3 b$ & $76.9 a b$ & $90.0 \mathrm{bc}$ & $4.7 a$ & $29.9 a b$ & $46.8 a$ & $77.1 \mathrm{bc}$ & $113.1 \mathrm{ab}$ \\
\hline $\begin{array}{l}W_{5} \text { skipping } \\
\text { at repining }\end{array}$ & $7.7 a b$ & $35.5 a$ & $65.4 a$ & $83.5 a$ & $107.0 a$ & $4.2 a b c$ & $32.2 a$ & $51.2 a$ & $95.3 a$ & $116.5 a$ \\
\hline LSD & 0.88 & 8.01 & 9.45 & 11.9 & 10.15 & 0.65 & 5.88 & 11.45 & 9.76 & 9.96 \\
\hline $\mathrm{SE}=$ & 0.37 & 2.7 & 3.1 & 4.0 & 4.6 & 0.22 & 2.0 & 3.8 & 3.2 & 3.7 \\
\hline CV\% & 8.6 & 16.6 & 11.9 & 10.6 & 7.4 & 10.9 & 14.2 & 16.4 & 8.1 & 6.4 \\
\hline
\end{tabular}

Means with the same letter in each column are not significant at 0.05 level of (LSD) test.

.Table 3: Effect of skipping irrigation on plant $/ \mathrm{m}^{2}$ and tiller/plant at developmental growth stages of wheat during $2008 / 09$ and $2009 / 010$ seasons:

\begin{tabular}{|c|c|c|c|c|}
\hline \multirow{2}{*}{$\begin{array}{l}\text { Treat } \\
\text { ments }\end{array}$} & \multicolumn{2}{|c|}{$2008 / 09$} & \multicolumn{2}{|c|}{$2009 / 010$} \\
\hline & Plant $/ \mathrm{m}^{2}$ & Tiller/plant & Plant $/ \mathrm{m}^{2}$ & Tiller/plant \\
\hline $\begin{array}{l}W_{S} \text { without } \\
\text { skipping }\end{array}$ & $176.9 a$ & $4.1 \mathrm{a}$ & $144.6 a$ & $4.1 \mathrm{ab}$ \\
\hline $\begin{array}{l}\text { W }{ }_{1} \text { skipping at } \\
\text { seedling }\end{array}$ & $171.9 a$ & $3.9 a b$ & $143.3 a$ & $4.2 a$ \\
\hline $\begin{array}{l}W_{2} \text { skipping at } \\
\text { tillering }\end{array}$ & $178.9 a$ & $3.7 \mathrm{~b}$ & $143.4 a$ & $4.0 a b$ \\
\hline $\begin{array}{l}\mathrm{W}_{3} \text { skipping at } \\
\text { booting }\end{array}$ & $190.6 a$ & $3.8 \mathrm{~b}$ & $145.7 a$ & $3.5 b$ \\
\hline $\begin{array}{l}W_{4} \text { skipping at } \\
\text { dough }\end{array}$ & $182.0 \mathrm{a}$ & $3.9 a b$ & $140.9 a$ & $3.8 \mathrm{ab}$ \\
\hline $\begin{array}{l}W_{5} \text { skippingat } \\
\text { repining }\end{array}$ & $191.4 a$ & $3.8 \mathrm{~b}$ & $143.4 a$ & $3.9 a b$ \\
\hline LSD & 26.8 & 0.28 & 14.5 & 0.64 \\
\hline SE士 & 9.2 & 0.15 & 3.6 & 0.21 \\
\hline CV\% & 9.8 & 4.9 & 5.1 & 11.2 \\
\hline
\end{tabular}

Means with the same letter in each column are not significant at 0.05 level of (LSD) test. 
Agric. Biol. J. N. Am., 2011, 2(6): 1003-1009

Table 4: Effect of skipping irrigation on yield components at developmental growth stages of wheat during 2008/09 and 2009/010 seasons:

\begin{tabular}{|c|c|c|c|c|c|c|c|c|}
\hline \multirow{2}{*}{$\begin{array}{l}\text { Treat } \\
\text { ments }\end{array}$} & \multicolumn{4}{|l|}{$2008 / 09$} & \multicolumn{4}{|l|}{$2009 / 010$} \\
\hline & Spike $/ \mathrm{m}^{2}$ & $\begin{array}{l}\text { Spikelet } \\
\text { /spike }\end{array}$ & $\begin{array}{l}\text { Grain } \\
\text { /spike }\end{array}$ & $\begin{array}{l}1000 \text { grain } \\
\text { weight }(\mathrm{g})\end{array}$ & Spike $/ \mathrm{m}^{2}$ & $\begin{array}{l}\text { Spikelet } \\
\text { /spike }\end{array}$ & $\begin{array}{l}\text { Grain } \\
\text { /spike }\end{array}$ & $\begin{array}{l}1000 \text { grain } \\
\text { weight(g) }\end{array}$ \\
\hline $\begin{array}{l}W_{S} \text { without } \\
\text { skipping }\end{array}$ & $243.8 a$ & $46.2 a$ & $40.6 a$ & $38.5 a$ & $227.9 a$ & $47.4 a$ & $44.1 a$ & $37.5 a$ \\
\hline $\begin{array}{l}\text { W }_{1} \text { skipping } \\
\text { at seedling }\end{array}$ & $228.3 a$ & $42.2 a$ & $37.4 a$ & $37.1 \mathrm{a}$ & $234.2 a$ & $42.4 a b c$ & $38.3 b c$ & $37.7 a$ \\
\hline $\begin{array}{l}\text { W }_{2} \text { skipping } \\
\text { at tillering }\end{array}$ & $197.8 b$ & $35.2 b$ & $29.5 b$ & $34.2 b$ & $211.1 b$ & $39.9 b c$ & $34.1 \mathrm{~cd}$ & $35.4 \mathrm{bc}$ \\
\hline $\begin{array}{l}\text { W }_{3} \text { skipping } \\
\text { at booting }\end{array}$ & $187.3 b$ & $35.0 \mathrm{~b}$ & $27.6 b$ & $33.6 b$ & $210.8 b$ & $37.9 c$ & $30.7 d$ & $35.7 \mathrm{bc}$ \\
\hline $\begin{array}{l}\text { W }{ }_{4} \text { skipping } \\
\text { at dough }\end{array}$ & $249.4 a$ & $42.2 a$ & $36.1 \mathrm{a}$ & $39.1 a$ & $227.9 a$ & 42.6abc & $38.6 \mathrm{bc}$ & $35.0 \mathrm{c}$ \\
\hline $\begin{array}{l}\text { W5skipping } \\
\text { at repining }\end{array}$ & $240.0 a$ & $44.5 a$ & $38.9 a$ & $37.7 a$ & $230.4 a$ & $45.6 a b$ & $41.5 a b$ & $36.7 a b$ \\
\hline LSD & 26.39 & 5.93 & 5.62 & 2.84 & 14.54 & 1.76 & 5.24 & 1.36 \\
\hline SE= & 9.9 & 2,0 & 1.6 & 0.9 & 4.8 & 1.8 & 0.45 & 0.45 \\
\hline CV\% & 7.8 & 9.6 & 10.6 & 5.1 & 4.3 & 8.3 & 9.2 & 2.5 \\
\hline
\end{tabular}

Means with the same letter in each column are not significant at 0.05 level of (LSD) test.

In both seasons the present study grain yield was significantly reduced under skipping In both seasons the present study grain yield was significantly reduced under skipping irrigation treatments due to lower number of tiller/plant, number of spike $/ \mathrm{m}^{2}$, number of spikelet/spike, number of grains/spike and 1000-grain weight. In table $(5,6)$ the highest grain and straw yield and biomass from (control and skipping at seedling, dough and repining stages) might be obtained due to availability of enough moisture at critical stages tillering and booting. It could be conclude that tillering and booting are the most important critical stages in the wheat crop regarding requirement of water, while the irrigation at repining stage decrease in wheat grain yield $\left(W_{5}\right)$ highest than the control $\left(W_{S}\right)$ in the second season). These results are in conformity with finding of Bajwa et al. (1993), Khahlown and Azam (2002) and Chauhan et al. (2008) who stated that application of five irrigations to wheat crop resulted in the highest grain yield. Wajid et al., (2007) also described that interaction between cultivar and irrigation levels affect the response of grain yield to water received was significant. With increasing soil moisture depletion by decreasing the amount of irrigation progressively from ear-emergence to harvest, these greater with Omer (1983) found reduced straw and grain yields.
The Water use efficiency is expressed as $\mathrm{kg}$ grain $/ \mathrm{m}^{3}$ water consumed by the wheat plants. This criterion has been used to evaluate the crop production under different applied treatments. In table (6) the presented findings are in harmony with the scientific approaches that supposed the plant roods could be extract more soil water from a greater depth under conditions stress as a compared to those irrigated at relatively wet. That means the stored water in soil at water stress can be used with more efficiency. These results are in agreement with those reported by El Hadi and Khadr (2003) indicated that wheat responded to water stress conditions. Haikel and Melegy (2005) conducted that the maximum grain yield and lowest water use efficiency of wheat was recorded at irrigated with recommended requirement under sandy soils conditions and sprinkler irrigation system.

The skipping irrigation also increased the harvest index slightly in both season (Table 6). The lower harvest index in the first season was due to the taller plants with a few spikes and grains which contributed to straw yield and hence resulted in low harvest indexes. 
Agric. Biol. J. N. Am., 2011, 2(6): 1003-1009

Table 5: Effect of skipping irrigation of grain and straw yield at developmental growth stages of wheat during 2008/09 and 2009/010 seasons:

\begin{tabular}{|c|c|c|c|c|c|c|c|c|c|c|c|c|}
\hline \multirow[b]{2}{*}{$\begin{array}{l}\text { Treat } \\
\text { ments }\end{array}$} & \multicolumn{6}{|l|}{2008} & \multicolumn{6}{|l|}{2009} \\
\hline & $\begin{array}{l}\text { Grain } \\
\text { yield } \\
\mathrm{kg} / \mathrm{ha}\end{array}$ & $\begin{array}{l}\text { Red- } \\
\text { com- } \\
\text { tow2 }\end{array}$ & $\begin{array}{l}\text { Red- } \\
\%\end{array}$ & $\begin{array}{l}\text { Straw } \\
\text { yield } \\
\mathrm{kg} / \mathrm{ha}\end{array}$ & $\begin{array}{l}\text { Red- } \\
\text { com- } \\
\text { tow2 }\end{array}$ & $\begin{array}{l}\text { Red- } \\
\%\end{array}$ & $\begin{array}{l}\text { Grain } \\
\text { yield } \\
\mathrm{kg} / \mathrm{ha}\end{array}$ & $\begin{array}{l}\text { Red- } \\
\text { com- } \\
\text { tow2 }\end{array}$ & $\begin{array}{l}\text { Red- } \\
\%\end{array}$ & $\begin{array}{l}\text { Straw } \\
\text { yield } \\
\mathrm{kg} / \mathrm{ha}\end{array}$ & $\begin{array}{l}\text { Red- } \\
\text { com- } \\
\text { tow2 }\end{array}$ & $\begin{array}{l}\text { Red- } \\
\%\end{array}$ \\
\hline $\begin{array}{l}\text { WSwithout } \\
\text { skipping }\end{array}$ & $2837 a$ & 0 & 0 & $6018 a$ & 0 & 0 & $3071 a$ & 0 & 0 & $5830 a$ & 0 & 0 \\
\hline $\begin{array}{l}\text { W }_{1} \text { skipping } \\
\text { at seedling }\end{array}$ & $2626 a$ & 211 & 7.4 & $4861 \mathrm{~b}$ & 1157 & 19.2 & $3067 a$ & 4.0 & 0.1 & $5296 a b$ & 534 & 9.2 \\
\hline $\begin{array}{l}\mathrm{W}_{2} \text { skipping } \\
\text { at tillering }\end{array}$ & $2193 b$ & 644 & 22.7 & $4360 \mathrm{~b}$ & 1658 & 27.6 & $2626 b c$ & 445 & 14.5 & $4303 b$ & 1527 & 26.2 \\
\hline $\begin{array}{l}W_{3} \text { skipping } \\
\text { at booting }\end{array}$ & $1913 c$ & 924 & 32.6 & $3409 c$ & 2609 & 43.4 & $2574 c$ & 497 & 16.2 & $4448 b$ & 1382 & 23.7 \\
\hline $\begin{array}{l}\text { W } 4 \text { skipping } \\
\text { at dough }\end{array}$ & $2628 a$ & 209 & 7.7 & $4728 b$ & 1290 & 21.4 & $2897 a b$ & 174 & 5.7 & $6336 a$ & +506 & +8.7 \\
\hline $\begin{array}{l}W_{5} \text { skipping } \\
\text { at repining }\end{array}$ & $2745 a$ & 92 & 3.2 & $5978 a$ & 40 & 0.7 & $3093 a$ & +22 & +0.7 & $6259 a$ & +429 & +7.4 \\
\hline LSD & 258.8 & & & 844.7 & & & 283.4 & & & 1249 & & \\
\hline $\mathrm{SE}=$ & 110.9 & & & $280 . .2$ & & & 94.0 & & & 414.2 & & \\
\hline CV\% & 6.9 & & & 11.4 & & & 6.5 & & & 15.3 & & \\
\hline
\end{tabular}

Means with the same letter in each column are not significant at 0.05 level of (LSD) test.

Table 6: Effect of skipping irrigation on biomass, Harvest Index and Water Use Efficiency at developmental growth stages of wheat during $2008 / 09$ and 2009/010 seasons:

\begin{tabular}{|c|c|c|c|c|c|c|}
\hline \multirow[t]{2}{*}{ Treatments } & \multicolumn{3}{|l|}{$2008 / 09$} & \multicolumn{3}{|l|}{$2009 / 010$} \\
\hline & $\begin{array}{l}\text { Biomass } \\
\mathrm{kg} / \mathrm{ha}\end{array}$ & $\begin{array}{l}\text { WUE } \\
\mathrm{kg} / \mathrm{mm} / \mathrm{ha}\end{array}$ & $\begin{array}{l}\text { Harvest index } \\
\%\end{array}$ & $\begin{array}{l}\text { Biomass } \\
\mathrm{kg} / \mathrm{ha}\end{array}$ & $\begin{array}{l}\text { WUE } \\
\mathrm{kg} / \mathrm{mm} / \mathrm{ha}\end{array}$ & $\begin{array}{l}\text { Harvest index } \\
\%\end{array}$ \\
\hline $\begin{array}{l}\text { W without } \\
\text { skipping }\end{array}$ & $8798 a$ & $4.05 a$ & $29.9 b$ & $8900 a$ & $4.17 \mathrm{~b}$ & $34.5 \mathrm{bc}$ \\
\hline $\begin{array}{l}W_{1} \text { skipping at } \\
\text { seedling }\end{array}$ & $7487 b$ & 3.86ab & $35.2 a$ & $7617 \mathrm{~b}$ & $4.52 a$ & $40.8 a$ \\
\hline $\begin{array}{l}\mathrm{W}_{2} \text { skipping at } \\
\text { tillering }\end{array}$ & $6553 c$ & $3.64 \mathrm{bc}$ & $33.5 a b$ & $6929 b$ & $3.97 b$ & $38.1 \mathrm{ab}$ \\
\hline $\begin{array}{l}W_{3} \text { skipping at } \\
\text { booting }\end{array}$ & $5329 d$ & $3.24 \mathrm{c}$ & $36.3 a$ & $7022 b$ & $3.95 b$ & $36.9 a b c$ \\
\hline $\begin{array}{l}\text { W }{ }_{4} \text { Skipping at } \\
\text { dough }\end{array}$ & $7350 \mathrm{bc}$ & $3.85 a b$ & $35.7 a$ & $9233 a$ & $4.29 a b$ & $31.4 \mathrm{c}$ \\
\hline $\begin{array}{l}W_{5} \text { skipping at } \\
\text { repining }\end{array}$ & $8723 a$ & 3.93ab & $31.3 a b$ & $9352 a$ & $4.56 a$ & $32.8 \mathrm{bc}$ \\
\hline LSD & 877.6 & 0.399 & 5.01 & 1095 & 0.421 & 6.17 \\
\hline $\mathrm{SE}=$ & 328.0 & 0.13 & 1.7 & 386.0 & 0.44 & 2.0 \\
\hline CV\% & 7.9 & 9.0 & 9.9 & 6.6 & 3.8 & 11.4 \\
\hline
\end{tabular}

* Means with the same letter in each column are not significant at 0.05 level of (LSD) test.

\section{SUMMARY AND CONCLUSION:}

In this study, generally, the results showed that the means of growth and yield attributes of wheat under skipping irrigation was relatively lower in the first season than in the second season due to the weather climate condition and Afides insects.

The highest grain yield from (control and skipping at seedling, dough and repining stages) might be obtained due to availability of enough moisture at critical stages tillering and booting. It could be conclude that tillering and booting are the most important critical stages in the wheat crop regarding requirement of water, while the irrigation at repining decrease in wheat yield.

To overcome the shortage of irrigation water, it is therefore, essential that we must use the available water resources carefully. In this regard, besides improvement in the system, over and under irrigation to crops should be avoided and irrigations be applied on crop water requirement basis using modern methods of irrigation. 


\section{RECOMMENDATION}

1. Skipping two or three irrigations during seedling, dough and repining stages had no effect on economic yield and save $10-30 \%$ from total irrigation costs of wheat production under Khartoum condition.

2. Skipping irrigation during tillering and booting stages must be avoided.

3. More researches were needed to detect grown field crops in Khartoum State.

\section{REFERENCES}

Akram, M.M. 2000. Effect of irrigation and nitrogen levels on the growth, yield and quality of wheat, M.sc. Thesis, Depart of Agronomy, University of Agriculture, Fasialabad.

Ali, M.H and M.S.U. Talukder, 2008. Increasing Water Productivity in Crop Production. A synthesis. Agric. Water Manage., 95: 1201-1213.

Anonymous. 1986. MSTAT-C. Micro statistical Program, Michigan State University, Michigan, Lansing, USA.

Awad, A.M., H.El- Zaher, M.A. Mostafa, M.A. Sayed and A.M. Osman, 2000. Wheat production on sandy soil using different fertilization methods and irrigation regimes. Alex. J. Agric. Res., 45(1): 35-61.

Babiker, E.A. and H. Faki. 1994. Evaluation of farmers' attitudes and their effect on wheat productivity and input use in Rahad Scheme. ICARDA/ARC. Wad Medani, Sudan.

Bajwa, M.A., M.H. Chaudary and A. Sattar. 1993. Influence of different irrigation regimes on yield and yield components of wheat. Pakistan Journal of Agricultural Research. 14(4): 353-365.

Chauhan, C.P.S., R. Bsingh and S.K. Cupta. 2008 Supplemental irrigation of wheat with saline water. Agricultural water Management 95: 253-258.

Cooper, J.L. 1980. The effect of nitrogen fertilization and irrigation frequency on a semi-dwarf wheat in south-east Australia in Growth and yield. Aust. J. Exp. Agric. Anim. Husb. 20: $359-364$.

El Hadi, A.H.A and M.S Khadr, 2003. Effect of Potassium Fertilization under Saline and drought Condition in Egyptian Soils. Potassium and water management in West Asia and North Africa Proceedings of the Regional. Workshop of the International Potash Institute. Ammar. Jordan, from 5 -5 November 2003. Pp: $85-91$.

FAO, Statistic division. 2007: Sudan.

Farah, S.M., S.H. Ahmed, Ahmed A. Salih, Hassan M. Ishag and Badr Eldin A. Mohamed., 1994a. Effect of
Skipping Irrigation at Different Developmental Stages of Wheat. Pages 1-5 in Nile Valley Regional Coordination Meeting 1-4 October 1994. Cairo. Egypt.

Ferrar, G.O.; Rajaran, S. and Mosaad, M.G. 1994. Breeding strategies for improving wheat in heatstressed environment ICARDA, Aleppo, Syria, 24-32.

Haikle, M.A and A. M. El Melegy, 2005. Effect of irrigation requirements, seeding rates and bio-mineral fertilizer on wheat productivity in newly reclaimed soil under sprinkler irrigation system. J. Productivity and Development, 10 (1):113-134.

Hussain, M. 1996. Impact of varying level of irrigations and phosphorus on the growth and yield of lentil. M.sc. Thesis, Department of Agronomy. University of Agriculture, Fasalabad.

Kahlown, M.A and M. Azam. 2002. Individual and Combined effect of Water Logging and Salinity on Crop yield in the Indus Basin. Journal of International Communication, Irrigation and Drainage 51(4): 329338.

Mc Master, G. S., 1999. Phenology, development and growth of wheat (Triticum aestivum L.) Shoot apex: A review. Adv. Agron. 59-63-118.

Mohammed, I. Maarouf, 2009. Genotype X Environment Interaction in Bread Wheat in Northern Sudan Using AMMI Analysis. American-Eurasian J.Agric.\&Environ.Sc., 6(4):427-433.

spikelet in wheat due to water deficit. Aust. J. Exp. Agric. Anim. Husb., 11:349-351.

Rathor, P.S (2005). Techniques and Management of Field Crop Production. Wheat. Updesh Purohif for Agrobios (India), Jodhpur. P $96-120$.

Schneider, A.D. and T.A. Howell, 1997. Methods, amounts and timing of sprinkler irrigation for winter wheat. Transaction of the ASAE., 40(1): 137 - 142.

Steel, R.G.D., J.H. Torrie and D.A. Dickey, 1997. Principles and Procedures of statistics. A Biometrical Approach, 3rd Ed. Mc Graw Hill Book co., New York, $172-177$.

Steiner, J.L.; Smith, G.G.; Meyer, W.S. and Adeney, A.J. 1985. Water use, foliage tenup. And yield of irrigated wheat in south-east Australia. Aus. J. Agric. Res. 36: 3-11.

Squie, G.K., Marshal, B. and Ong, C.K., 1989. Development and growth of pearl millet (pennisetum typhoides) in response to water supply and demand. Volume 22, Expl. Agric. pp 289-299.

Wajid. A., K. Hussain, M. Maqsood, A. Ahmad and A. Hussain. 2007. Influence of drought on water use efficiency in wheat in semi-arid regions of Punjab. Soil and Environment 26(1): 64-68. 